\title{
A Tolnai-hegyhát zárt lösztölgyesei (Pulmonario mollis-Quercetum roboris Kevey 2008)
}

\author{
KEVEY Balázs ${ }^{1}$, HORVÁTH András ${ }^{2}$, LENDVAI Gábor ${ }^{3}$ és SIMON György ${ }^{4}$ \\ ${ }^{1}$ Pécsi Tudományegyetem, Ökológiai Tanszék, 7624 Pécs, Ifjúság u. 6.; \\ keveyb@gamma.ttk.pte.hu \\ ${ }^{2}$ Vak Bottyán Általános Iskola és Gimnázium, 7081 Simontornya, Hunyadi u. 15.; \\ horvath.a.zs@gmail.com \\ 37000 Sárbogárd, Ady E.u. 162.; gaborlendvai@hotmail.com \\ ${ }^{4} 8000$ Székesfehérvár, Király sor 41.; tepuisimon@gmail.com
}

Elfogadva: 2018. október 10.

Kulcsszavak: Délnyugat-Magyarország, erdei löszvegetáció, szüntaxonómia.

Összefoglalás: Jelen tanulmány a Dél-Dunántúl északkeleti peremén levő Tolnai-hegyhát zárt lösztölgyeseinek (Pulmonario mollis-Quercetum roboris) cönológiai elemzése 50 felvétel alapján. Az összehasonlító elemzésbe további három tájegység zárt lösztölgyes felvételeit és a Tolnai-hegyhát nyílt lösztölgyeseinek (Aceri tatarici-Quercetum pubescentis-roboris) felvételeit is bevontuk. Az eredmények szerint a vizsgált asszociáció állományai az erdők félszáraz-félüde termőhelyein fordulnak elő, és átmenetet képeznek a száraz nyílt lösztölgyesek (Aceri tatarici-Quercetum pubescentis-roboris) és az üde talajú gyertyános-tölgyesek (Corydali cavae-Carpinetum) között. E zárt lösztölgyesek (Pulmonario mollis-Quercetum roboris) az alföldi lösztáblákon a homokvidékekről ismert - ugyancsak félszáraz-félüde talajú - zárt homoki tölgyeseket (Convallario-Quercetum roboris) helyettesítik. A társulás felépítésében a száraz gyepek elemei (Festuco-Brometea, Festucetalia valesiacae, Festucion rupicolae stb.), amelyek a nyílt lösztölgyesekben (Aceri tatarici-Quercetum pubescentisroboris) még jelentős szerepet játszanak, itt már alárendeltek. A száraz erdők karakterfajai (Quercetea pubescentis-petraeae, Quercetalia cerridis, Aceri tatarici-Quercion) ezzel szemben még hasonlóan gyakoriak, mint a nyílt lösztölgyesekben. A félüde termőhely miatt aljnövényzetükben mezofil jellegü fajok (Querco-Fagetea, Fagetalia, Carpinenion) is megjelennek, amelyek szintén elkülönítik a társulást a nyílt lösztölgyesektől. A löszvölgyek alját borító gyertyános-tölgyesektől (Corydali cavae-Carpinetum) elsősorban a száraz tölgyesek elemeinek (Quercetea pubescentispetraeae, Quercetalia cerridis, Aceri tatarici-Quercion) nagyobb részarányával és több mezofil jellegü (Querco-Fagetea, Fagetalia, Carpinenion) faj hiányával különböznek. A Tolnai-hegyhát vizsgált erdőtársulása a sokváltozós elemzések (cluster-analízis, ordináció) révén is elkülönült. A zárt lösztölgyes (Pulmonario mollis-Quercetum roboris Kevey 2008) a „Polygonato latifolio-Quercenion roboris Kevey 2008" alcsoportba (suballiance) sorolható.

\section{Bevezetés}

Az üde jellegü zárt lösztölgyesekre (Pulmonario mollis-Quercetum roboris) Kevey Balázs 1994-ben figyelt fel (KeveY 2008, 2011). Kutatócsoportunk 2004- 
ben kezdte meg a Mezőföld és peremvidéke tatárjuharos-tölgyeseinek (Aceri tatarici-Quercetum pubescentis-roboris) és zárt lösztölgyeseinek (Pulmonario mollis-Quercetum roboris) felmérését (vö. LendVAI et al. 2014a, 2014b; PURGER et al. 2014, KeVEY et al. 2015, HorvÁTH A. et al. 2017). E munka keretén belül kezdtük el a Tolnai-hegyhát tölgyeseinek tanulmányozását is. A táj flóráját PILLICH sen. (1928) és Pillich jun. (1930a, 1930b, 1931) óta gyakorlatilag nem kutatták, viszont a közölt florisztikai adatok biztató eredményeket ígértek. Jelen közlemény a Tolnai-hegyhát zárt lösztölgyeseinek jellemzését tartalmazza.

\section{Anyag és módszer}

\section{A kutatási terület jellemzése}

Kutatási területünk a Tolnai-hegyhát, amely Dél-Dunántúl flóravidékének (Praeillyricum) északkeleti peremén fekszik, és közvetlenül érintkezik az Alföld flóravidékéhez (Eupannonicum) tartozó Mezőfölddel. A táj BoRHIDI (1961) klímazonális térképe szerint az alföldi erdőssztyepp zónába tartozik. Ennek értelmében a tetőkön a tatárjuharos-tölgyesek (Aceri tatarici-Quercetum pubescentisroboris) képezhetnék a zonális erdőtársulást. Állományait azonban nem a löszplatókon, hanem a platók peremén, ill. az innen kiinduló ormókon láttuk, míg a platókat általában cseres-tölgyesek (Potentillo micranthae-Quercetum dalechampii) borítják. A zárt lösztölgyesek (Pulmonario mollis-Quercetum roboris) elsősorban a xeromezofil völgyoldalakon, ritkábban a völgyek alján találhatók, ahol gyakran gyertyános-tölgyesekkel (Corydali cavae-Carpinetum) érintkeznek. Állományaik ennek megfelelően extrazonálisak. A zárt lösztölgyesek (Pulmonario mollisQuercetum roboris) leírására az alföldi lösztáblák és a homokbuckák vegetációkeresztmetszete közötti hasonlóság alapján került sor (KEVEY 2008, 2011). Ez a hasonlóság elsősorban abban nyilvánul meg, hogy a homoki asszociációkat löszön hasonló asszociációk helyettesítik (részletesen lásd: KEVEY et al. 2015).

2005 és 2017 között alaposan bejártuk a táj erdeit. Felmérésre érdemes erdőket csak a Tolnai-hegyhát északi peremén találtunk Pálfa, Simontornya, Kisszékely és Nagyszékely határában. A vizsgált állományok 150-200 m tengerszint feletti magasságban fordulnak elő. Az alapkőzet mindenütt lösz. E zárt lombkoronájú lösztölgyesek helyenként meglepően nagy - egy-két hektárnyi - kiterjedésủek (Kisszékely: Babaszó, Dukai-hegy; Pálfa: Kis-erdő; Simontornya: Csirka-völgy). Többségük a változatos domborzattal rendelkező lösztáblák északias kitettségü, 5-30 fokos lejtőin, és völgyoldalain található. Mikroklímájuk viszonylag meleg-félszáraz, talajuk a félszáraz-félüde tartományba sorolható. 


\section{Alkalmazott módszerek}

Összehasonlítás céljából az elemzésekbe a Tolnai-hegyhát erdeiben készült felvételek mellett bevontuk a más tájakról közölt zárt lösztölgyes (Pulmonario mollis-Quercetum roboris) felvételeket (Kerecsend: KeVEY 2011; Harkány-Nagynyárádi-sík: KEVEY 2016; Zámolyi-medence: KEVEY et al. 2015), valamint a Tolnai-hegyhátról eddig még nem közölt nyílt lösztölgyesek (Aceri tatarici-Quercetum pubescentis-roboris) felvételeit is.

A cönológiai felvételek a Zürich-Montpellier növénycönológiai iskola (BECKING 1957; BRAUN-BLANQUET 1964) hagyományos kvadrátmódszerével készültek. A felvételek táblázatos összeállítása, valamint a karakterfajok csoportrészesedésének és csoporttömegének számítása az „NS” számítógépes programcsomaggal (KEVEY és HiRMANN 2002) történt. A felvételkészítés és a hagyományos statisztikai számítások kissé módosított módszere KEVEY (2008) tanulmányában megtalálható. A Syn-Tax 2000 programcsomag (PODANI 2001) segítségével sokváltozós elemzéseket is végeztünk. E téren bináris adatokon alapuló hierarchikus osztályozást, cluster-analízist (hasonlósági index: Baroni-Urbani-Buser; osztályozó módszer: teljes lánc, illetve csoport átlag), és szintén bináris alapú ordinációt (hasonlósági index: Baroni-Urbani-Buser; ordinációs módszer: főkoordináta-analízis) készítettünk.

A fajok esetében KIRÁly (2009), a társulásoknál pedig BorHIDI és KEVEY (1996), KeVEY (2008), illetve BoRHIDI et al. (2012) nómenklatúráját követjük. A társulástani és a karakterfaj-statisztikai táblázatok felépítése az újabb eredményekkel (Oberdorfer 1992, Mucina et al. 1993, Kevey 2008, Borhidi et al. 2012) módosított Soó (1980) féle cönológiai rendszerre épül. A növények cönoszisztematikai besorolásánál is elsősorban Soó (1964, 1966, 1968, 1970, 1973, 1980) Synopsisára támaszkodtunk, de figyelembe vettük az újabb kutatási eredményeket is (vö. BorHidi 1993, 1995; HoRVÁtH F. et al. 1995).

\section{Eredmények}

\section{Fiziognómia}

A Tolnai-hegyhát zárt lösztölgyeseinek cönológiai felvételezéséből származó információkat az E1. és E2. táblázat foglalja össze. A vizsgált zárt lösztölgyesek felső lombkoronaszintje az állomány korától és a termőhelyi viszonyoktól függően 18-30 m magas, és közepes vagy erősebb záródást mutat (60-80\%). Állandó (K: IV-V) fája a Quercus cerris és a Fraxinus excelsior. Nagyobb tömegben (AD: 3-4) előforduló fái a Fraxinus excelsior, a Quercus cerris, a Quercus pubescens 
és a Quercus robur. E viszonylag zárt szintben lékek csak ritkán fordulnak elö. $\mathrm{Az}$ alsó lombkoronaszint fejlettebb, mint a nyílt lösztölgyeseknél (Aceri tatariciQuercetum pubescentis-roboris), fái a felső lombkoronaszintben levő lékeket többnyire elzárják. A fák magassága 12-22 m, borításuk pedig 10-50\%. Állandó (K: IV) fája csak az Acer campestre, s nagyobb tömeget (A-D:3) is csak e fafaj képez.

A cserjeszint fejlettsége igen változó. Magassága 2-4 m, borítása pedig 2080\%. Állandó (K: V) elemei az Acer campestre, a Cornus mas és a Crataegus monogyna. Nagyobb tömeget (A-D: 3-4) e három faj mellett olykor csak a Staphylea pinnata képez. Az alsó cserjeszint (újulat) általában fejletlen, 1-25\% borítású. Állandó (K: IV-V) fajai az alábbiak: Acer campestre, Cornus mas, Crataegus monogyna, Fraxinus excelsior, Ligustrum vulgare, Quercus cerris, Ulmus minor. E szintben nagyobb tömegben (A-D: 3-4) előforduló faj nem akadt.

A gyepszint borítása 50-95\%. Állandó elemei (K: IV-V) a következők: Alliaria petiolata, Anemone ranunculoides, Brachypodium sylvaticum, Buglossoides purpuro-coerulea, Corydalis cava, Corydalis pumila, Dactylis polygama, Doronicum hungaricum, Elymus caninus, Fallopia dumetorum, Geranium robertianum, Geum urbanum, Glechoma hirsuta, Mercurialis ovata, Piptatherum virescens, Poa nemoralis, Polygonatum latifolium, Ranunculus ficaria, Rumex sanguineus, Scilla vindobonensis, Stellaria holostea, Urtica dioica, Veratrum nigrum, Veronica sublobata, Viola suavis. E szintben több lágy szárú növény is nagyobb tömegben fordul elő (A-D: 3-5): Anemone ranunculoides, Corydalis cava, Glechoma hirsuta, Melica uniflora, Mercurialis ovata, Polygonatum latifolium, Stellaria holostea.

Fajkombináció

Állandósági osztályok eloszlása

Az 50 cönológiai felvétel alapján a vizsgált zárt lösztölgyesekben 19 konstans és 14 szubkonstans faj szerepel az alábbiak szerint: K V: Acer campestre, Anemone ranunculoides, Brachypodium sylvaticum, Cornus mas, Corydalis cava, Corydalis pumila, Crataegus monogyna, Dactylis polygama, Fallopia dumetorum, Fraxinus excelsior, Geum urbanum, Glechoma hirsuta, Mercurialis ovata, Polygonatum latifolium, Quercus cerris, Ranunculus ficaria, Rumex sanguineus, Stellaria holostea, Veronica sublobata; K IV: Acer tataricum, Alliaria petiolata, Buglossoides purpuro-coerulea, Elymus caninus, Doronicum hungaricum, Geranium robertianum, Ligustrum vulgare, Piptatherum virescens, Poa nemoralis, Scilla vindobonensis, Ulmus minor, Urtica dioica, Veratrum nigrum, Viola suavis ( E1. táblázat). A társulásból továbbá 15 akcesszórikus (K III), 33 szubakcesszórikus (K II) és 112 akcidens (K I) faj került elő (E1. táblázat). Az állandósági osztályokat tekintve tehát az akcidens (K I) elemek mellett a konstans (K V) fajoknál mutatkozik egy gyengébb második maximum (1. ábra). 


\section{Sokváltozós statisztikai elemzések eredményei}

Mind a cluster-analízis dendrogramján (2-3. ábra), mind pedig az ordinációs diagramon (4. ábra) öt-öt csoport jött létre. A Tolnai-hegyhát nyílt lösztölgyese (Aceri tatarici-Quercetum pubescentis-roboris) egyértelmü elkülönülést mutat. A zárt lösztölgyesek (Pulmonario mollis-Quercetum roboris) felvételei is - földrajzi tájanként - különülnek el egymástól, bár a közöttük levő távolság már lényegesen kisebb (2. ábra).

A két társulásba sorolt, illetve négy különböző földrajzi területről származó felvételek jól értelmezhető csoportokat alkotnak. A sokváltozós elemzések szerint a nyílt lösztölgyes (Aceri tatarici-Quercetum pubescentis-roboris) minden elemzés szerint tökéletesen elválik a zárt lösztölgyesektől (Pulmonario mollis-Quercetum roboris) (2-3. ábra). Utóbbiak közül a Zámolyi-medence és Kerecsend felvételei jól elkülönülő, de egymással rokon csoportokat alkotnak. A Harkány-Nagynyárádisík felvételcsoportja kevésbé egységes, és részben a Zámolyi-medence és Kerecsend felvételeihez, részben a Tolnai-hegyhát felvételcsoportjához mutat affinitást (2-3. ábra). A jelen tanulmány homlokterében álló felvételek, azaz a Tolnai-hegyhát zárt lösztölgyes felvételei az ordinációs diagramon aránylag nagy pontfelhőt alkotnak. Viszonylag kis kohéziójuk ellenére azonban mind a más tájakon készült zárt lösztölgyes felvételektől, mind a földrajzilag közel álló, de más társulásba tartozó nyílt lösztölgyesektől jól elkülönülnek (4. ábra).

\section{Fajszám}

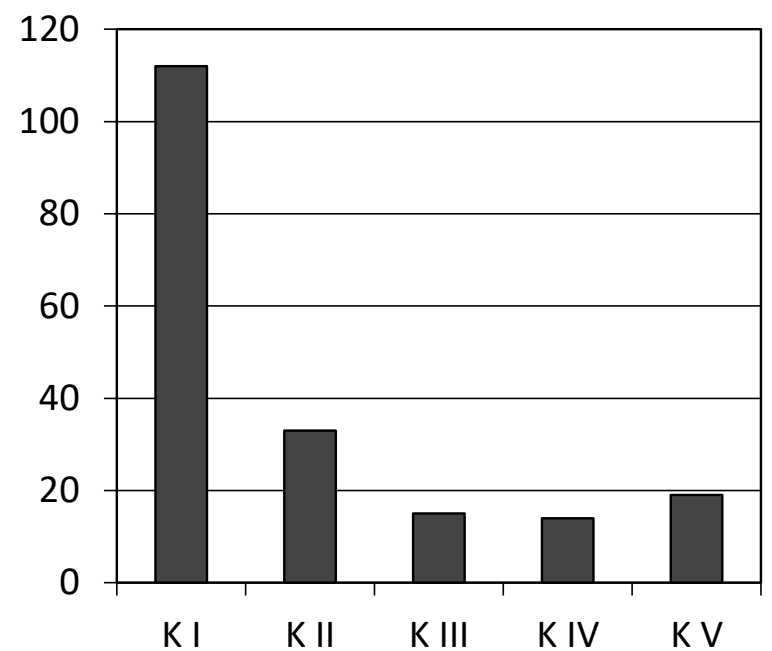

1. ábra. Az állandósági osztályok eloszlása a Tolnai-hegyhát zárt lösztölgyeseiben (Pulmonario mollis-Quercetum roboris)

Fig. 1. Distribution of constancy classes of the Pulmonario mollis-Quercetum roboris forests of the Tolna Hills 
Kevey B. et al.

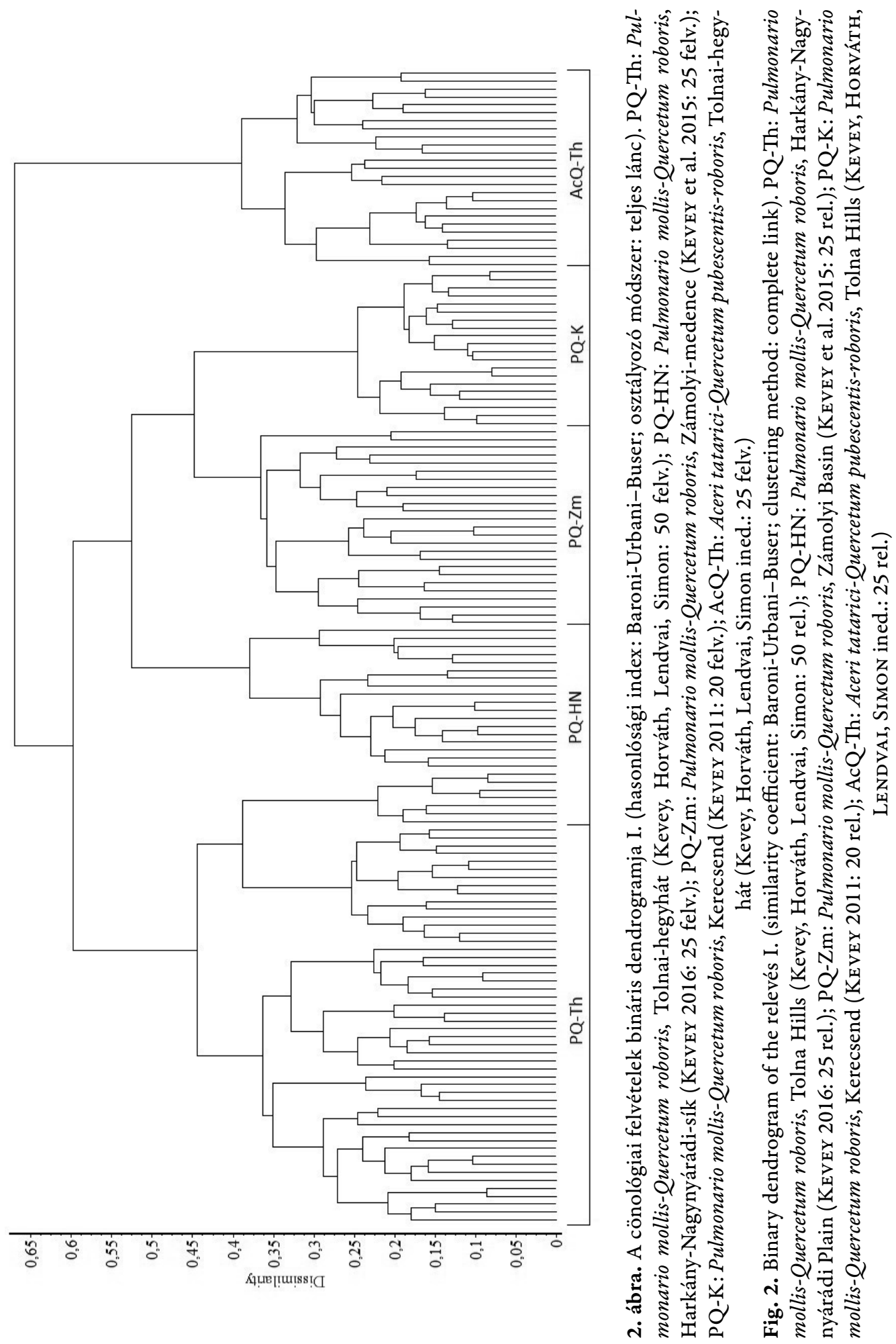




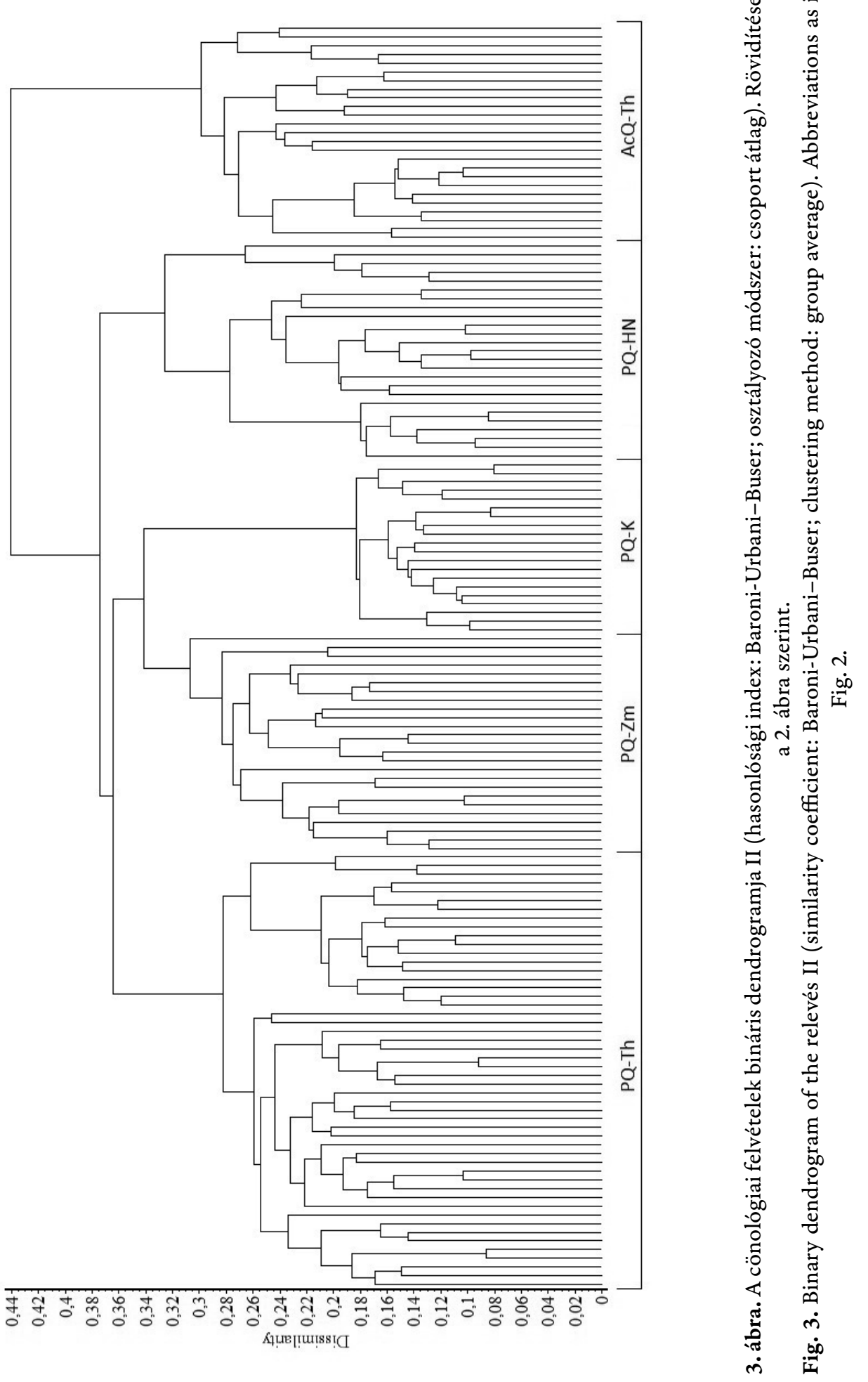




\section{Karakterfajok aránya}

A vizsgált zárt lösztölgyesekben (Pulmonario mollis-Quercetum roboris) a nyílt lösztölgyesekhez (Aceri tatarici-Quercetum pubescentis-roboris) képest erösen visszaszorulnak a száraz gyepek növényei (Festuco-Bromea s. l. incl. FestucoBrometea, Festucetalia valesiacae et Festucion rupicolae). Csoportrészesedésük $1,73 \%$, csoporttömegük pedig mindössze $0,18 \%$ (E1. és E3. táblázat; 5 . ábra).

A zárt lösztölgyesek felépítésében a legjelentősebb szerepet a száraz tölgyesek elemei (Quercetea pubescentis-petraeae incl. Quercetalia cerridis, Quercion farnetto, Quercion petraeae, Aceri tatarici-Quercion) képezik. E Quercetea pubescentis-petraeae s. 1. elemek 33,44\% csoportrészesedést és 37,14\% csoporttömeget mutatnak (E1. és E3. táblázat; 6. ábra). Arányuk tehát hasonló, mint az alföldi tájak zárt lösztölgyeseiben, de csoporttömegük lényegesen kisebb, mint a Tolnaihegyhát nyílt lösztölgyeseiben (Aceri tatarici-Quercetum pubescentis-roboris).

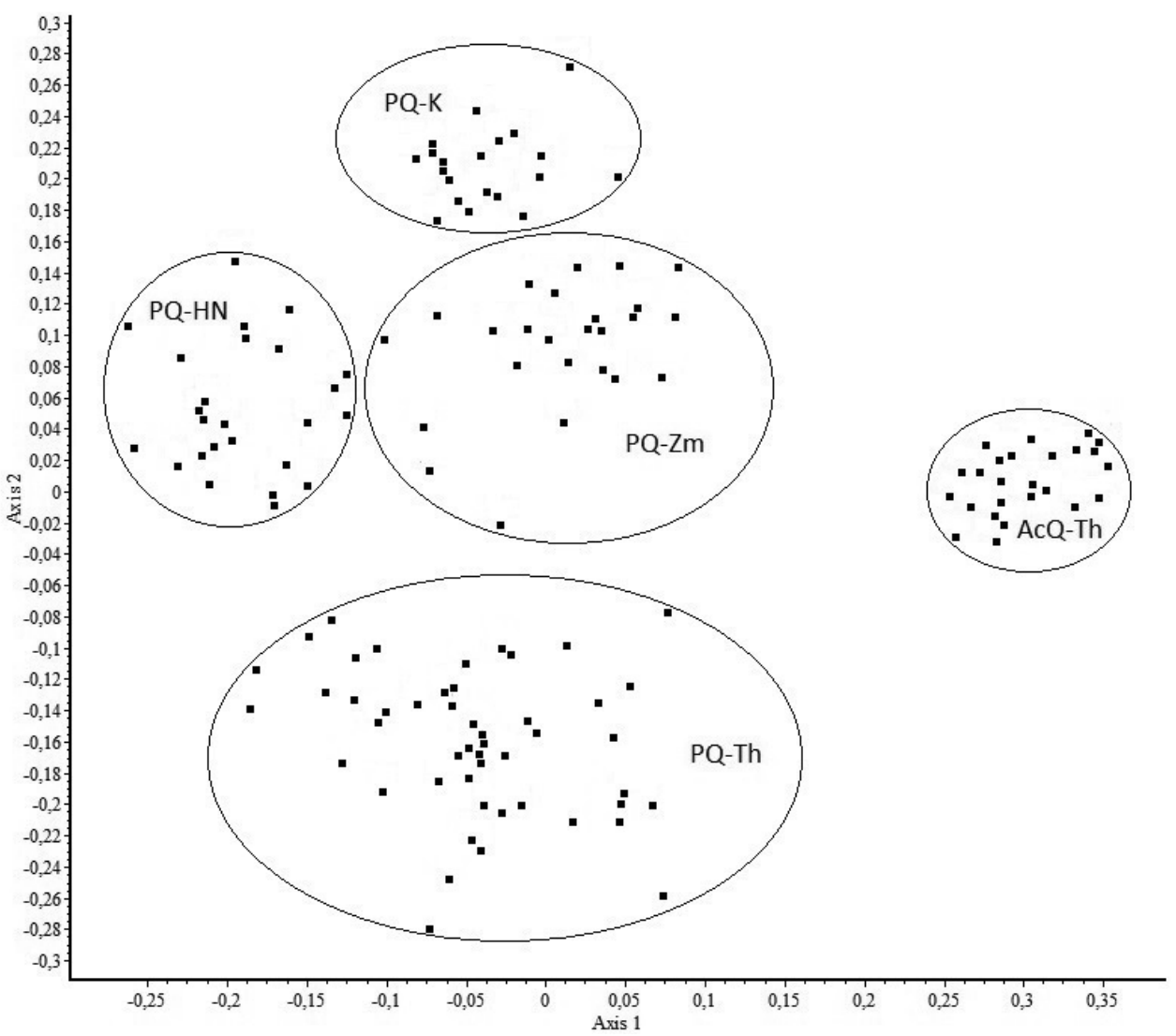

4. ábra. A cönológiai felvételek bináris ordinációs diagramja (hasonlósági index: Baroni-UrbaniBuser; ordinációs módszer: főkoordináta-analízis). Rövidítések a 2. ábra szerint.

Fig. 4. Diagram of the binary ordination of the relevés (similarity coefficient: Baroni-Urbani-Buser; ordinációs módszer: principal coordinates analysis). Abbreviations as in Fig. 2. 
Nagy számmal vannak olyan növények is, amelyek a tágabb értelemben vett mezofil jellegü lomberdők (Querco-Fagetea) karakterfajai, de részben xerofil (Quercetea pubescentis-petraeae) jelleget is mutatnak (E1. és E3. táblázat). Ezeknél azonban jelentősebbek a valódi mezofil lomberdei elemek (Fagetalia incl. Alnion incanae, Carpinenion, Tilio-Acerenion és Aremonio-Fagion). E növények $12,13 \%$ csoportrészesedést és $21,46 \%$ csoporttömeget érnek el. Arányuk tehát lényegesen nagyobb, mint a nyílt lösztölgyesekben (Aceri tatarici-Quercetum pubescentis-roboris) (E1. és E3. táblázat; 7. és 8. ábra). E téren figyelemre méltó az, hogy a Harkány-Nagynyárádi-síkon az Alnion incanae elemek aránya milyen magas értéket mutat (3,58\% csoportrészesedés, $6,13 \%$ csoporttömeg).

\section{Flóraelemek aránya}

A flóraelemek kapcsán feltűnő, hogy a közép-európai fajok a zárt lösztölgyesekben (Pulmonario mollis-Quercetum roboris) jóval gyakoribbak (17,09\% csoportrészesedés, 33,63\% csoporttömeg), míg a nyílt lösztölgyesekben (Aceri tatarici-Quercetum pubescentis-roboris) arányuk lényegesen kisebb (9,4\% csoportrészesedés, 7,62\% csoporttömeg; 4. táblázat, 9. ábra).

A szubmediterrán elemek esetében fordított a helyzet. Ezek aránya ugyanis a nyílt lösztölgyesekben (Aceri tatarici-Quercetum pubescentis-roboris) nagyobb (19,86\% csoportrészesedés, $45,86 \%$ csoporttömeg) és a zárt lösztölgyesekben (Pulmonario mollis-Quercetum roboris) kisebb (16,64\% csoportrészesedés, 19,47\% csoporttömeg; 4. táblázat, 10. ábra).

Végül érdemes szemügyre venni a kontinentális, föleg a pontusi flóraelemek arányát, amelyek szintén nyílt lösztölgyesekben (Aceri tatarici-Quercetum pubescentis-roboris) mutatják a legmagasabb értéket ( $9,8 \%$ csoportrészesedés, $10,21 \%$ csoporttömeg), míg a zárt lösztölgyesekben elért értékük jóval alacsonyabb (5,34\% csoportrészesedés, $8,40 \%$ csoporttömeg). Itt feltünő, hogy a Harkány-Nagynyárádi-síkon e fajok aránya milyen alacsony (3,18\% csoportrészesedés, 1,69\% csoporttömeg). Fontosabb pontusi jellegü fajok a következők: Acer tataricum, Ajuga laxmannii, Arum orientale, Buglossoides purpuro-coerulea, Carex michelii, Cornus mas, Euonymus verrucosus, Euphorbia salicifolia, Iris variegata, Lysimachia punctata, Mercurialis ovata, Piptatherum virescens, Polygonatum latifolium, Rosa gallica (E1. és E4. táblázat; 11. ábra).

Összességében megállapítható, hogy a Tolnai-hegyhát zárt lösztölgyeseiben (Pulmonario mollis-Quercetum roboris) a szubmediterrán elemek aránya mintegy kétszer akkora, mint a kontinentális elemeké. A legmagasabb értéket azonban mindkét flóraelem a nyílt lösztölgyesekben (Aceri tatarici-Quercetum pubescentis-roboris) éri el. 


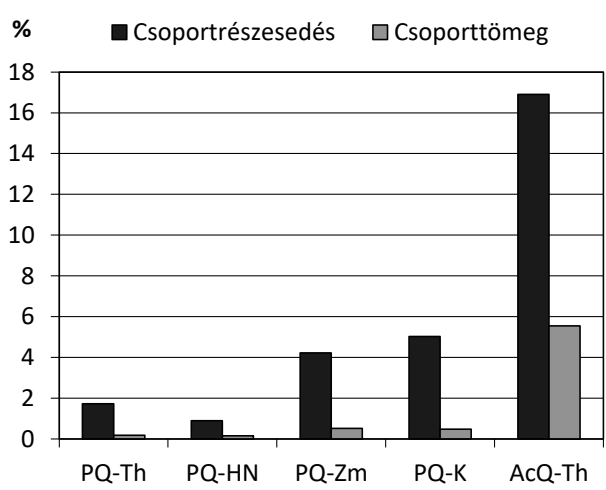

5. ábra. Festuco-Brometea s. 1. fajok aránya. Rövidítések a 2. ábra szerint.

Fig. 5. Percentage of species characteristic of dry grasslands. Csoportrészesedés $=$ Relative frequency; Csoporttömeg = Relative frequency weighted with cover values. Abbreviations as in

Fig. 2.

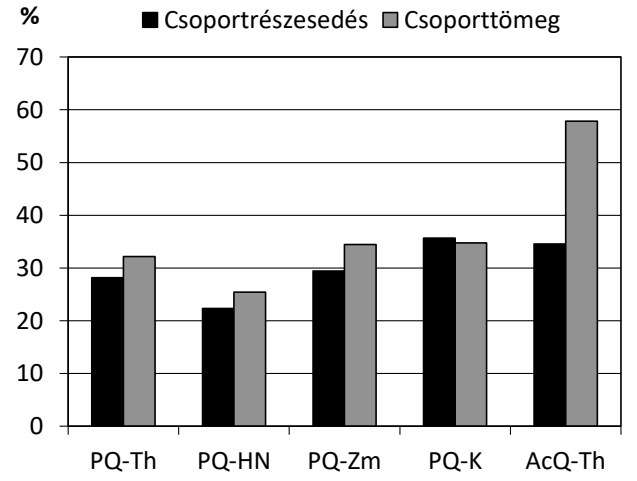

6. ábra. Quercetea pubescentis-petraeae fajok aránya. Rövidítések a 2 . ábra szerint.

Fig. 6. Percentage of species characteristic of the class Quercetea pubescentis-petraeae. Csoportrészesedés $=$ Relative frequency; Csoporttömeg = Relative frequency weighted with cover values. Abbreviations as in Fig. 2.

\section{A zárt lösztölgyesek differenciális fajai}

A Tolnai-hegyhát zárt (Pulmonario mollis-Quercetum roboris) és nyílt (Aceri tatarici-Quercetum pubescentis-roboris) lösztölgyesei között számos olyan differenciális fajt találunk, amelyek állandósága legalább két fokozat különbséget mutat (E5. táblázat). Vannak ugyan közöttük közönséges növények is, a zárt

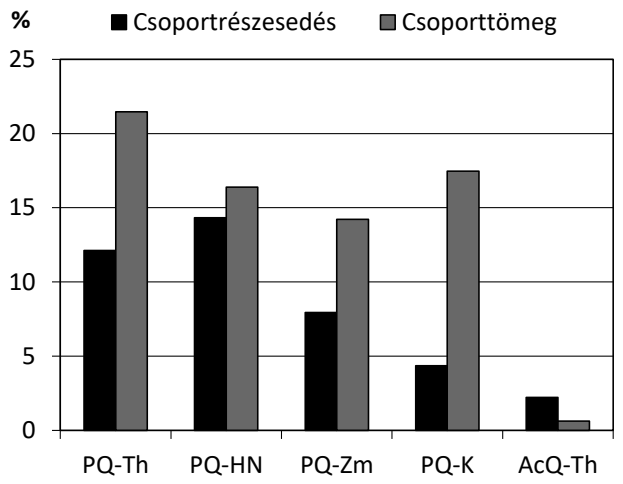

7. ábra. Fagetalia fajok aránya. Rövidítések a 2. ábra szerint.

Fig. 7. Percentage of species characteristic of the order Fagetalia. Csoportrészesedés = Relative frequency; Csoporttömeg = Relative frequency weighted with cover values. Abbreviations as in Fig. 2.

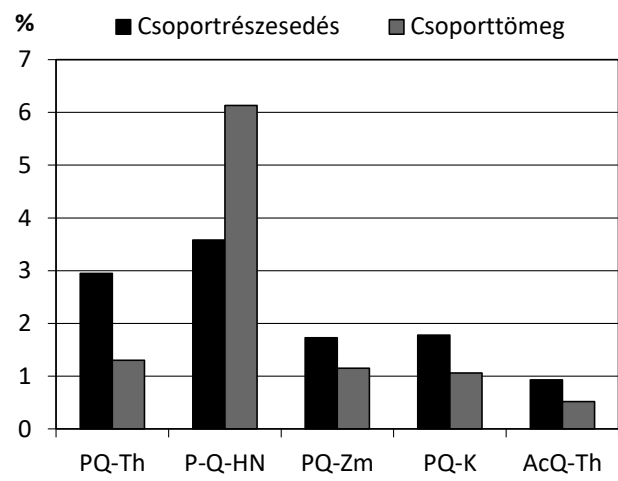

8. ábra. Alnion incanae s. l. fajok aránya. Rövidítések a 2. ábra szerint.

Fig. 8. Percentage of species characteristic of the alliance Alnion incanae. Csoportrészesedés $=$ Relative frequency; Csoporttömeg $=$ Relative frequency weighted with cover values. Abbreviations as in Fig. 2. 


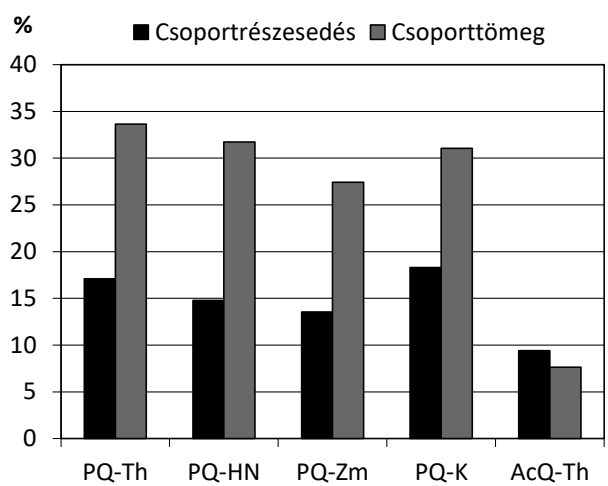

9. ábra. Közép-európai flóraelemek aránya. Rövidítések a 2. ábra szerint.

Fig. 9. Percentage of central European floristic elements. Csoportrészesedés $=$ Relative frequency; Csoporttömeg = Relative frequency weighted with cover values. Abbreviations as in Fig. 2.

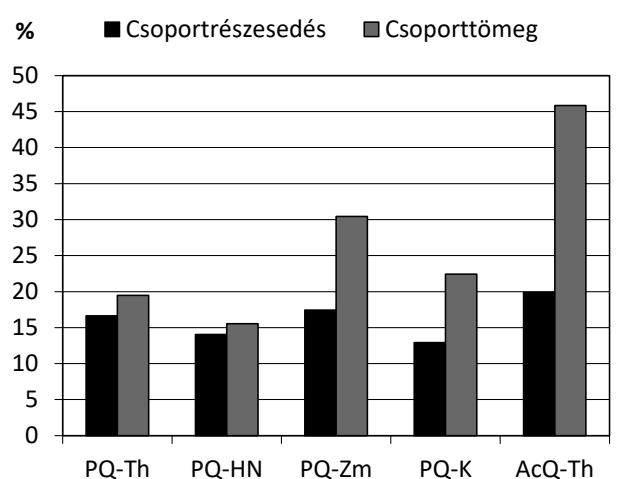

10. ábra. Szubmediterrán flóraelemek aránya. Rövidítések a 2. ábra szerint.

Fig. 10. Percentage of sub-Mediterranean floristic elements. Csoportrészesedés $=$ Relative frequency; Csoporttömeg = Relative frequency weighted with cover values. Abbreviations as in

Fig. 2.

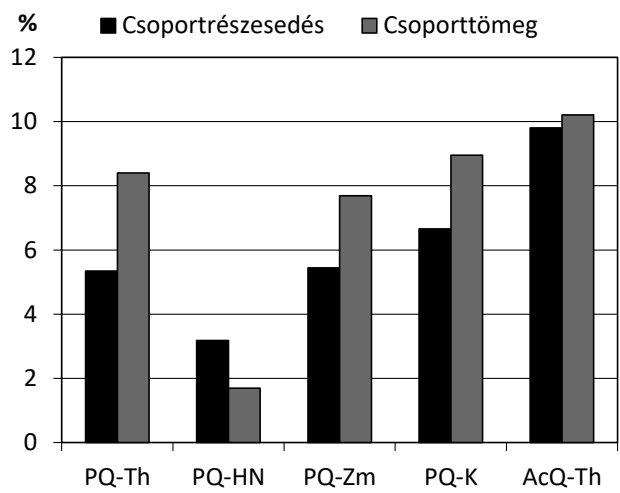

11. ábra. Pontusi flóraelemek aránya. Rövidítések a 2. ábra szerint.

Fig. 11. Percentage of continental, Pontic floristic elements. Csoportrészesedés $=$ Relative frequency; Csoporttömeg = Relative frequency weighted with cover values. Abbreviations as in

Fig. 2.

lösztölgyesek differenciális fajainak mégis mintegy kétharmada mezofil jellegü (Fagetalia, Querco-Fagetea) elem: Ajuga reptans, Anemone ranunculoides, Campanula trachelium, Cardamine bulbifera, Carpinus betulus, Corydalis cava, Glechoma hirsuta, Lilium martagon, Moehringia trinervia, Myosotis sparsiflora, Poa nemoralis, Polygonatum multiflorum, Ranunculus ficaria, Scilla vindobonensis, Sta- 
chys sylvatica, Stellaria holostea, Veratrum nigrum, Viola reichenbachiana stb. A nyílt lösztölgyesekben ezzel szemben a differenciális fajok túlnyomó részét a száraz gyepek (pl. Festuco-Brometea, Festucetalia valesiacae, Festucion rupicolae) és a száraz erdők ( $p l$. Quercetea pubescentis-petraeae, Quercetalia cerridis, Aceri tatarici-Quercion) karakterfajai képezik: Achillea pannonica, Adonis vernalis, Ajuga laxmannii, Anchusa barrelieri, Arabis turrita, Asparagus officinalis, Berberis vulgaris, Campanula bononiensis, Carex michelii, Cleistogenes serotina, Colutea arborescens, Dictamnus albus, Erysimum diffusum, Euonymusverrucosus, Euphorbia epithymoides, Falcaria vulgaris, Festuca valesiaca, Filipendula vulgaris, Fragaria viridis, Galium glaucum, Inula germanica, Iris pumila, Medicago falcata, Melica transsilvanica, Polygonatum odoratum, Potentilla arenaria, Pseudolysimachion spicatum, Stachys recta, Taraxacum laevigatum, Teucrium chamaedrys, Thalictrum minus, Thymus pannonicus, Verbascum phoeniceum, Viburnum lantana, Vinca herbacea, Viola hirta stb.

\section{Természetvédelmi vonatkozások}

Az 50 cönológiai felvétel alapján e zárt lösztölgyesekből 13 védett növényfaj került elö: K IV: Doronicum hungaricum, Scilla vindobonensis. K II: Dictamnus albus, Lilium martagon. K I: Aconitum anthora, Ajuga laxmannii, Cephalanthera damasonium, Galanthus nivalis, Phlomis tuberosa, Iris variegata, Lychnis coronaria, Orchis purpurea, Thalictrum aquilegiifolium. A vizsgált zárt lösztölgyesek (Pulmonario mollis-Quercetum roboris) kitűnő állapotúak, hazai vegetációnk üde foltjait képezik. Ezen erdők jelenleg a Natura 2000 területek közé tartoznak. Botanikai-természetvédelmi értékeiknél fogva helyi jelentőségü védett területté történő nyilvánításuk folyamatban van.

\section{Megvitatás}

A karakterfajok aránya hasonlóan alakult, mint a Kerecsendi-erdőben (KeVEy 2011), a Zámolyi-medencében (KeVEY et al. 2015) és a Harkány-Nagynyárádi-síkon (KeVEY 2016). Ezzel megerősítést nyert az, hogy hasonló termőhely esetén az asszociáció állományai egymástól távol is kialakulhatnak, továbbá a zárt lösztölgyesek (Pulmonario mollis-Quercetum roboris) mindenütt a száraz talajú nyílt lösztölgyesek (Aceri tatarici-Quercetum pubescentis-roboris) és az üde termőhelyü gyertyános-tölgyesek (Corydali cavae-Carpinetum) között képeznek átmenetet. A nyílt lösztölgyesekhez képest a száraz gyepek elemei (FestucoBromea s. 1.) erősen megritkulnak, a mezofil jellegü lomberdei fajok (QuercoFagetea, Fagetalia) viszont jóval gyakoribbá válnak.

A sokváltozós elemzések (2-4. ábra) során a Tolnai-hegyhát nyílt lösztölgyesei (Aceri tatarici-Quercetum pubescentis-roboris) fajkészletük alapján egyér- 
telműen elváltak a zárt lösztölgyesektől (Pulmonario mollis-Quercetum roboris). Az utóbbi asszociáció négy tájegységből származó felvételei is elkülönültek tájanként, bár a teljes lánc futtatási mód esetében a Harkány-Nagynyárádi-sík néhány felvétele a Tolnai-hegyhát felvételeinek csoportjába került (2. ábra). Ez ugyanakkor további bizonyíték arra nézve, hogy az elemzett zárt lösztölgyesek (Tolnaihegyhát, Harkány-Nagynyárádi-sík, Zámolyi-medence, Kerecsend) egy asszociációhoz tartoznak.

Fenti vizsgálati eredmények megerősítik azt a korábbi feltevést (KEVEY 2008), mely szerint az önálló erdőtársulásként leírt zárt lösztölgyesek (Pulmonario mollis-Quercetum roboris) a lösztáblák völgyeiben a homokvidékekről már régen ismert zárt homoki tölgyeseket (Convallario-Quercetum roboris) helyettesítik. Állományai nem azonosíthatók a nyílt lösztölgyesek (Aceri tatarici-Quercetum pubescentis-roboris) viszonylag zártabb koronaszintủ szubasszociációival (lithospermetosum purpureo-coerulei, galietosum schultesii) (Zólyomi 1957, 1967; KEVEY 2011, ZÓLYOMI et al. 2013), sem pedig a Magyar-középhegység molyhos tölgyeseivel (Vicio sparsiflorae-Quercetum pubescentis, Corno-Quercetum pubescentis) (IsÉPY 1970, KEVEY 2008, 2011). Az asszociáció helye a növénytársulások rendszerében az alábbi módon vázolható:

Divízió: Querco-Fagea Jakucs 1967

Osztály: Querco-Fagetea Br.-Bl. et Vlieger in Vlieger 1937 em. Borhidi in Borhidi et Kevey 1996

Rend: Quercetalia cerridis Borhidi in Borhidi et Kevey 1996

Csoport: Aceri tatarici-Quercion Zólyomi et Jakucs 1957

Alcsoport: Polygonato latifolio-Quercenion roboris Kevey 2008

Társulás: Pulmonario mollis-Quercetum roboris Kevey 2008

\section{Köszönetnyilvánítás}

Köszönetünket fejezzük ki Fekete Gábor† akadémikus úrnak hasznos tanácsaiért, valamint az anonim lektoroknak a javító szándékú észrevételeikért.

\section{Irodalomjegyzék}

Becking, R. W. 1957: The Zürich-Montpellier School of Phytosociology. Botanical Review 23: 411-488. https://doi.org/10.1007/bf02872328

Borhidi A. 1961: Klimadiagramme und klimazonale Karte Ungarns. Annales Universitatis Scientiarum Budapestinensis de Rolando Eötvös Nominatae, Sectio Biologica 4: 21-50.

BorHIDi A. 1993: A magyar flóra szociális magatartás típusai, természetességi és relatív ökológiai értékszámai. Janus Pannonius Tudományegyetem, Pécs, 95 pp.

BorHIDI A. 1995: Social behaviour types, the naturalness and relative ecological indicator values of the higher plants in the Hungarian Flora. Acta Botanica Hungarica 39: 97-181. 
Borhidi A., KeVey B. 1996: An annotated checklist of the Hungarian plant communities II. In: BORHIDI A. (ed.): Critical revision of the Hungarian plant communities (Ed.: BorHIDI A.). Janus Pannonius University, Pécs, pp. 95-138.

Borhidi A., Kevey B., Lendvai G. 2012: Plant communities of Hungary. Akadémiai Kiadó, Budapest, $544 \mathrm{pp}$.

BRAun-Blanquet, J. 1964: Pflanzensoziologie Grundzüge der Vegetationskunde (3rd ed.). Springer Verlag, Wien-New York, 865 pp. https://doi.org/10.1007/978-3-7091-8110-2

Horváth A., Kevey B., Lendvai G., Simon Gy., Sonnevend I. 2017: Tatárjuharos-tölgyesek (Aceri tatarici-Quercetum pubescentis-roboris Zólyomi 1957) az Észak-Mezőföldön és a Zámolyi-medence környékén. Botanikai Közlemények 104(1): 109-130.

https://doi.org/10.17716/BotKozlem.2017.104.1.109

Horváth F., Dobolyi Z. K., Morschhauser T., Lökös L., Karas L., Szerdahelyi T. 1995: Flóra adatbázis 1.2.Taxon-lista és attribútium állomány. MTA Ökológiai és Botanikai Kutatóintézete, Vácrátót, $267 \mathrm{pp}$.

IsÉPY I. 1970: Phytozönologische Untersuchungen und Vegetationskartierung im südöstlichen Vértes-Gebirge. Acta Botanica Academiae Scientiarum Hungaricae 16(1-2): 59-110.

JAKUCS P. 1967: Gedanken zur höheren Systematik der europäischen Laubwälder. Contribuții Botanice, Cluj-Napoca (1967): 159-166.

Kevey B. 2008: Magyarország erdőtársulásai (Forest associations of Hungary). Die Wälder von Ungarn. Tilia 14: 1-488. (+ CD-adatbázis: 244 ábra +230 táblázat).

Kevey B. 2011: Zárt lösztölgyesek a Kerecsendi-erdőben (Pulmonario mollis-Quercetum roboris Kevey 2008). Botanikai Közlemények 98(1-2): 79-116.

Kevey B. 2016: A Harkány-Nagynyárádi-sík zárt lösztölgyesei. Kaposvári Rippl-Rónai Múzeum Közleményei 4: 31-56.

KeVey B., HirmanN, A. 2002: „NS” számítógépes cönológiai programcsomag. In: Aktuális flóraés vegetációkutatások a Kárpát-medencében V. Pécs, 2002. március 8-10. (Összefoglalók), p. 74.

Kevey B., Horváth A., Lendvai G., Simon Gy., Sonnevend I. 2015: A Zámolyi-medence és környékének zárt lösztölgyesei (Pulmonario mollis-Quercetum roboris Kevey 2008). Botanikai Közlemények 102(1-2): 85-129. https://doi.org/10.17716/BotKozlem.2015.102.1-2.85

KIrÁly G. (szerk.) 2009: Új magyar füvészkönyv. Magyarország hajtásos növényei. Határozókulcsok. Aggteleki Nemzeti Park Igazgatóság, Jósvafö, 616 pp.

Lendvai G., Horváth A., Kevey B. 2014a: Tatárjuharos tölgyesek (Aceri tatarici-Quercetum pubescentis-roboris Zólyomi 1957) a Mezőföldön. Botanikai Közlemények 101(1-2): 145-187.

Lendvai G., Kevey B., Horváth, A. 2014b: A Velencei-hegység tatárjuharos tölgyesei (Aceri tatarici-Quercetum pubescentis-roboris Zólyomi 1957). Botanikai Közlemények 101(1-2): 189-226.

Mucina, L., Grabherr, G., Wallnöfer, S. (eds.) 1993: Die Pflanzengesellschaften Österreichs III. Wälder und Gebüsche. Gustav Fischer, Jena - Stuttgart - New York, 353 pp.

Oberdorfer, E. 1992: Süddeutsche Pflanzengesellschaften IV. A. Textband. Gustav Fischer Verlag, Jena - Stuttgart - New York, 282 pp.

Pillich F. sen. 1928: Adatok Tolnavármegye flórájához. Magyar Botanikai Lapok 26(1927): 94-97.

Pillich F. jun. 1930a: Simontornya és környéke flórája (1921-1930). Pázmány Péter Tudományegyetem Bölcsészeti Kar, Budapest, 74 pp. (kézirat)

PILliCH F. jun. 1930b: „Simontornya és környéke flórája”-nak gyógyszerészeti vonatkozásai. Gyógyszerészhallgatók Értesítője 2(6-8): 17-32.

Pillich F. jun. 1931: A Satureja Pillichiana J. Wagn. jellemzése. Botanikai Közlemények 27(5-6): 105-111. (1930). 
PodAni J. 2001: Syn-Tax 2000 Computer programs for data analysis in ecology and systematics. Scientia, Budapest, $53 \mathrm{pp}$.

Purger D., Lengyel A., Kevey B., Lendvai G., Horvát h A., Tomić, Z., Csiky J. 2014: Numerical classification of oak forests on loess in Hungary, Croatia and Serbia. Preslia 86: 47-66.

Soó R. 1964, 1966, 1968, 1970, 1973, 1980: A magyar flóra és vegetáció rendszertani-növényföldrajzi kézikönyve I-VI. Akadémiai kiadó, Budapest.

VLIEGER, J. 1937: Aperçu sur les unités phytosociologiques supérieures des Pays-Bas. Nederlandsch Kruidkundig Archief 47: 335-353.

Zólyomi B. 1957: Der Tatarenahorn-Eichen-Lösswald der zonalen Waldsteppe (Acereto tatariciQuercetum). Acta Botanica Academiae Scientiarum Hungaricae 3: 401-424.

Zólyomi B. 1967: Aceri tatarico-Quercetum pubescenti-roboris (hungaricum). In: Zólyomi B. (ed.): Guide der Exkursionen des Internationalen Geobotanischen Symposiums. Ungarn, EgerVácrátót, 5-10, Juni 1967, pp. 51-54.

Zólyomi B., Jakucs P. 1957: Neue Einteilung der Assoziationen der Quercetalia pubescentis-petraeae-Ordnung im pannonischen Eichenwaldgebiet. Annales historico-naturales Musei Nationalis Hungarici 8: 227-229.

Zólyomi B., Horváth A., Kevey B., Lendvai, G. 2013: Steppe woodlands with Tatarian Maple (Aceri tatarici-Quercetum pubescentis-roboris) on the Great Hungarian Plain and its neighbourhood. An unfinished synthesis with supplementary notes. Acta Botanica Hungarica 55(1-2): 167-189. https://doi.org/10.1556/abot.55.2013.1-2.11

Elektronikus melléklet: E1-E5 táblázatok. Electronic supplement: Tables E1-E5.

E1. táblázat. Pulmonario mollis-Quercetum roboris felvételek.

Table E1. Pulmonario mollis-Quercetum roboris relevés.

E2. táblázat. A felvételek adatai.

Table E2. Relevés' data.

E3. táblázat. Karakterfajok aránya. Rövidítések a 2. ábra szerint.

Table E3. Percentage of characteristic species. Legends as in Fig. 2.

E4. táblázat. Flóraelemek aránya. Rövidítések a 2. ábra szerint.

Table E4. Percentage of floristic elements. Legends as in Fig. 2.

E5. táblázat. A Tolnai-hegyhát zárt és nyílt lösztölgyeseinek differenciális fajai. Rövidítések a 2. ábra szerint.

Table E5. Differentiating species between steppe woodlands and closed oak forests in the Tolna Hills. Legends as in Fig. 2. 


\title{
Closed dry oak forests in the Tolna Hills, Hungary (Pulmonario mollis-Quercetum roboris Kevey 2008)
}

\author{
B. KEVEY', A. HORVÁTH ${ }^{2}$, G. LENDVAI ${ }^{3}$, Gy. SIMON ${ }^{4}$ \\ ${ }^{1}$ University of Pécs, Department of Ecology, Ifjúság u. 6, H-7624 Pécs, Hungary; \\ keveyb@gamma.ttk.pte.hu \\ ${ }^{2}$ Vak Bottyán Primary and Secondary School, Hunyadi u. 15, H-7081 Simontornya, \\ Hungary; horvath.a.zs@gmail.com \\ ${ }^{3}$ Ady E. u. 162, H-7000 Sárbogárd, Hungary; gaborlendvai@hotmail.com \\ ${ }^{4}$ Széchenyi u. 35, H-8000 Székesfehérvár, Hungary; tepuisimon@gmail.com
}

Accepted: 10 October 2018

Key words: forest vegetation on loess, Southwest Hungary, syntaxonomy.

In the forest steppe vegetation of Hungary, the closed oak forest community (Pulmonario mollis-Quercetum roboris) growing on loess is phytosociologically the analogous counterpart of the closed oak forest on sand (Convallario-Quercetum roboris). In terms of its habitat characteristics and species composition, it is intermediate between steppe woodlands (Aceri tatarici-Quercetum pubescentisroboris) and the more mesic oak-hornbeam forest (Corydali cavae-Carpinetum). This community was found in the northeastern part of the Tolna Hills, where it often grows right next to open steppe woodlands. In this paper, we provide a phytosociological analysis of this community based on 50 relevés from stands growing in the Tolna Hills. The results indicate that this community clearly differs not only from the Turkey oak forest widespread in the area, but also from the often adjacent open steppe woodlands. 